\title{
ISOLASI KARAKTERISASI T ASAM HUMAT DAN PENENTUAN DAYA SERAP NYA TERHADAP ION LOGAM Pb(II) Cu(II) DAN Fe(II)
}

\author{
Yati B Yuliyati * \& Christi Liamita Natanael \\ Jurusan Kimia, Fakultas Matematika dan Ilmu Pengetahuan Alam, \\ Universitas Padjadjaran \\ Email: yatiyuliyati@yahoo.com
}

\begin{abstract}
Coal, which are decomposition resulted ofnatural biologicalprocessesover the yearsin which thehumicacidcompound contained.The purposes of this research was tocharacterize and to compare the humic acid of coal from South Borneo. The isolation of humic acid by leaching process usesnatrium karbonat $0.1 \mathrm{~N}$ and fractionation usessulfuric acid 6M. The fraction was purified and the deposit was washed by sulfuric acid 1 M, aquadestand ethanol. Moisture content, ash content, cation exchange capacity, C/N ratio and E4/E6ratiowithspectroscopy were characterized. The yields of humic acid areobtained $12.35 \%$ of coal. C/N ratio of humic acid 20.72. The infrared spectroscopy results of humic acid from coal figures more of aromatic and -OH groupwith lower E4/E6 ratio, while from peat soil shows more of aliphatic and carboxylic group supported higher E4/E6 ratio. Kapasitas tukar kation 640,59 mek/l00g; dan mempunyai daya serap terhadap ion logam yang cukup baik.
\end{abstract}

Keywords: Coal, humic acid.

\section{PENDAHUluan}

Asam humat adalah zat organik makromolekul polielektrolit, diketahui berkemampuan untuk berinteraksi sangat kuat dengan berbagai logam membentuk kompleks logam humat, dimana hal ini berpengaruh terhadap sifat adsorpsi-desorpsi dari logam.Ikatannya dengan ion logam adalah salah satu peranan yang penting dari fungsi asam humat sebagai adsorben. Menurut Aiken et al., asam humat merupakan senyawa humat yang tidak larut dalam air pada kondisi asam tetapi larut pada kondisi $\mathrm{pH}$ yang tinggi. Fungsional utama yang terdapat pada asam humat adalah asam karboksilat, alkohol, fenol, karbonil, fosfat, sulfat, amida, dan sulfide (Stevenson,1994).

Gyula (2012) telah melakukan penelitian tentang kemampuan asam humat dalam mengikat kontaminan logam berat $\mathrm{Ag}$ dan $\mathrm{Pb}$ yang berada pada limbah cair. Kemampuannya dalam membentuk kompleks dengan timah dan kadmium telah diteliti juga oleh Yong and Cynthia (2006). 


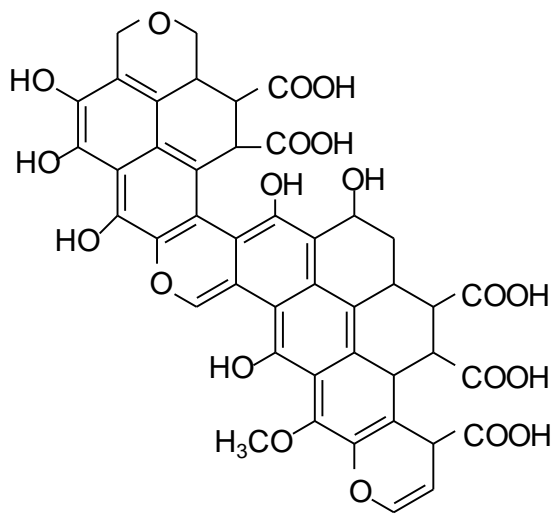

Gambar 1. Struktur hipotetik asam humat menurut Fuch (Stevenson, 1994).

Saat ini perkembangan berbagai jenis industri sangat pesat, sehingga akan menambah banyak jenis limbah yang kalau dibuang secara langsung tanpa pengolahan terlebih dapat menyebabkan pencemaran lingkungan, salah satu limbah tersebut adalah logam berat.

Semua mahluk hidup akan memerlukan logam berat, akan tetapi, pada jumlah berlebih, keberadaan logam berat tersebut dapat mengakibatkan dampak yang negatif baik untuk manusia atau mahluk hidup lainnya. Logam berat dapat mengakibatkan keracunan apabila terakumulasi dalam tubuh bahkan dapat menyebabkan kematian apabila kadarnya melebihi ambang batas. Supaya keberadaan logam tersebut tidak membahayakan maka perlu suatu upaya untuk mengurangi jumlah logam berat yang ada dalam lingkungan kehidupan kita. Salah satu cara adalah dengan memanfaatkan asam humat yang dapat diambil dari batubara

Adsorpsi adalah proses yang terjadi ketika gas atau zat terlarut cair terakumulasi pada permukaan padat atau cair (adsorben), membentuk lapisan film molekul atau atom (adsorbat) (Uhrikova, 2007). Interaksi ini terjadi karena adanya gaya tarik atom molekul pada permukaan zat padat dan membentuk lapisan tipis yang menutupi lapisan tersebut. Penelitian ini merupakan alternatif dalam mengurangi limbah $\operatorname{logam} \mathrm{Pb}, \mathrm{Cu}$ dan $\mathrm{Fe}$ dengan memanfaatkan asam humat hasil isolasi dari batubara.

\section{METODE PENELITIAN}

\section{Alat}

\section{Bahan Penelitian}

Bahan yang digunakan dalam penelitian ini adalah batubara muda (lignite) yang berasal dari provinsi Kalimantan Selatan didapatkan dari PT. Geoservice Bandung. Bahan ini merupakan sumber asam humat. 


\section{Prosedur Kerja}

Isolasi Asam Humat.

Larutan yang digunakan untuk mengisolasi asam humat adalah natrium karbonat $0,1 \mathrm{~N}$. Sebanyak 500 gram batubara diekstraksi dengan $5.000 \mathrm{~mL}$ larutan natrium karbonat $0,1 \mathrm{~N}$ selama 24 jam. Setelah ekstraksi, supernatan didiamkan sampai terbentuk dua lapisan kemudian disaring. Filtrat yang diperoleh diasamkan dengan asam sulfat $6 \mathrm{M}$ hingga terbentuk endapan . Endapan selanjutnya dilarutkan kembali dengan larutan natrium karbonat $0,1 \mathrm{~N}$. Endapan ini adalah asam humat yang tidak murni. Pemurnian asam humat dilakukan dengan cara melarutkan kembali ke dalam larutan natrium karbonat $0,1 \mathrm{~N}$ dan diendapkan dengan asam sulfat $6 \mathrm{M}$ sampai terbentuk endapan. Padatan yang diperoleh kemudian dicuci dengan asam sulfat $0,1 \mathrm{M}$ diikuti dengan akuades, etanol dan akuades kembali. Asam humat dikeringkan dalam oven pada suhu $50^{\circ} \mathrm{C}$.

\section{Karakterisasi Asam Humat \\ Penentuan Kadar Air}

Asam humat sebanyak $25 \mathrm{mg}$ dimasukkan ke dalam kui yang sebelumnya telah ditimbang. Kemudian dipanaskan pada suhu $105^{\circ} \mathrm{C}$ selama 24 jam. Setelah didinginkan dalam desikator berat kui ditimbang kembali.

\section{Penentuan Kadar Abu}

Asam humat sebanyak $25 \mathrm{mg}$ dimasukkan ke dalam kui yang sebelumnya telah ditimbang. Kemudian dipanaskan pada suhu $500^{\circ} \mathrm{C}$ selama 4 jam. Setelah didinginkan dalam desikator berat kui ditimbang kembali. Prinsip dari penentuan kadar abu dengan menggunakan tanur cara langsung yaitu dengan mengoksidasi zat organik pada suhu tinggi yaitu sekitar 500$600^{\circ} \mathrm{C}$ kemudian melakukan penimbangan zat yang tertinggal setelah proses pembakaran (Sudarmaji, 2007).

\section{Pengukuran Absorbansi dengan Spektrofotometer $U V$-visible}

Sebanyak $2 \mathrm{mg}$ asam humat baik asam humat sampel maupun standar dilarutkan dalam natrium bikarbonat $0,05 \mathrm{~N}$ sebanyak $40 \mathrm{~mL}$. Kemudian diukur absorbansinya pada panjang gelombang 200-800 $\mathrm{nm}$.

\section{Penentuan Kadar C Metode Walkey dan Black}


Asam humat sebanyak 0,05 g dimasukkan ke dalam erlenmeyer $500 \mathrm{~mL}$. Kemudian ditambahkan $10 \mathrm{ml}$ larutan kalium dikromat $0,5 \mathrm{~N}$ dan erlenmeyer tersebut dikocok sehingga larutan bercampur rata dengan pereaksi. Sebanyak $20 \mathrm{ml}$ asam sulfat pekat ditambahkan untuk membentuk suspensi dengan cepat, kemudian erlenmeyer dikocok dengan cepat hingga asam humat bercampur dengan pereaksi selama 1 menit. Erlenmeyer didiamkan hingga dingin selama 30 menit. Setelah dingin, ditambahkan $\pm 200 \mathrm{ml}$ akuadesdan $5 \mathrm{~mL}$ asam fosfat pekat ke dalam erlenmeyer. Lalu ditambahkan $1 \mathrm{~mL}$ indikator difenilamin dan dititrasi dengan larutan ferosulfat $0,5 \mathrm{~N}$ hingga warna hijau, lalu ditambah lagi $0,5 \mathrm{~mL}$ larutan kalium dikromat dan dititrasi kembali hingga warna hijau muncul kembali.

\section{Penentuan Kadar N Metode Kjehdahl}

Asam humat sebanyak $200 \mathrm{mg}$ dimasukkan ke dalam labu Kjehdahl dan ditambahkan 10 $\mathrm{mL}$ asam sulfat pekat. Kemudian dimasukkan campuran tembaga sulfat:kalium sulfat (1:8) sebanyak $5 \mathrm{~g}$ sebagai katalis. Lalu labu Kjehdal didestruksi hingga larutan berwarna hijau jernih. Larutan hasil destruksi diencerkan dalam labu ukur hingga $100 \mathrm{mLsetelah} \mathrm{larutan} \mathrm{berwarna} \mathrm{hijau}$ jernih. Larutan yang telah diencerkan dipipet sebanyak $10 \mathrm{~mL}$ dan dimasukkan ke dalam alat destilasi Kjehdahl. Kemudian ditambahkan $10 \mathrm{~mL}$ larutan natrium hidroksida 30\% dan didestilasi selama 20 menit. Destilat ditampung dalam erlenmeyer yang telah berisi asam klorida $0,1 \mathrm{M}$ sebanyak $25 \mathrm{~mL}$. Setelah 20 menit destilat dititrasi menggunakan larutan natrium hidroksida $0,1 \mathrm{M}$.

\section{Penentuan Kapasitas Tukar Kation}

Pasir silika sebanyak $6 \mathrm{~g}$ dicuci menggunakan larutan panas asam klorida $0,1 \mathrm{M}$ diikuti dengan akuades hingga $\mathrm{pH}$ netral. Kemudian kolom bersih dan kering diisi dengan glass woll lalu dimasukkan pasir silika hingga $\pm 2 \mathrm{~cm}$. Lalu kolom diisi dengan larutan amonium asetat $1 \mathrm{~N}$ hingga $\pm 1 \mathrm{~cm}$. Asam humat sebanyak $0,2 \mathrm{~g}$ dimasukkan dan dinding kolom dibilas dengan amonium asetat $1 \mathrm{~N}$. Sampel dielusi dengan amonium asetat $1 \mathrm{~N}$ sebanyak $100 \mathrm{~mL}$. Eluat yang didapat dibuang lalu dielusi kembali dengan etanol sebanyak $100 \mathrm{~mL}$. Eluat yang didapat dibuang dan dielusi kembali dengan larutan kalium klorida 10\% sebanyak $100 \mathrm{~mL}$. Eluat yang didapat ditampung lalu ditambahkan fenol, natrium nitroprusid dan oksidator untuk keperluan spektrofotometri UV-visible.

\section{Penentuan Daya Asam Humat Terhadap Ion Logam Pb(II), Cu(II) dan Fe(II)}

Proses adsorpsi dilakukan dengan metode batch. Proses adsorpsi dilakukan dengan menginteraksikan asam humat dengan ion-ion logam $\mathrm{Pb}(\mathrm{II}), \mathrm{Cu}$ (II) dan $\mathrm{Fe}(\mathrm{II})$ pada berbagai variasi waktu dan konsentrasi. 


\section{HASIL DAN PEMBAHASAN}

Asam humat hasil isolasi dari batubara dengan larutan pengekstrak natrium karbonat $0,1 \mathrm{~N}$ mengendap pada $\mathrm{pH}, 1,13 ; 1,18$ dan $\mathrm{pH} 2,24$. Diperoleh rendemen masing-masing 3,75; 6,43\% , dan $12,35 \%$. Kelarutan asam humat dalam alkali sebagai garam Na-humat dipengaruhi oleh $\mathrm{pH}$, dimana dengan semakin tingginya $\mathrm{pH}$ maka asam humat akan lebih mudah membentuk garam Na-humat. Ekstraksi asam humat didasarkan pada perpindahan komponen asam humat dari bahan asal ke dalam larutan pengekstrak.

Perpindahan mulai terjadi pada lapisan antar muka kemudian masuk ke dalam pelarut. Proses ini terjadi pada saat tahap pertama ekstraksi asam humat. Fraksinasi asam humat adalah pemisahan asam humat berdasarkan perbedaan kelarutannya pada $\mathrm{pH}$ rendah dan tinggi dimana asam humat tidak larut pada $\mathrm{pH}$ rendah sedangkan asam fulvat larut. Menurut Alimin dkk (2005) asam humat tidak larut pada $\mathrm{pH}$ lebih kcil 3 karena cenderung membentuk padatan polielektrolit, kaku (rigid) dan teragregrasi membentuk suatu padatan makromolekul melalui ikatan hidrogen.

Dengan menurunnya $\mathrm{pH}$ akan menyebabkan ikatan hidrogen semakin kuat sehingga agregat akan bergabung satu sama lain. Pada $\mathrm{pH}$ yang relatif rendah maka konsentrasi $\mathrm{H}+$ tinggi sehingga gugus-gugus fungsi yang terdapat pada asam humat sulit mengalami deprotonasi. Sulitnya deprotonasi gugus-gugus fungsional asam humat akan meningkatkan kemampuan pembentukan ikatan hidrogennya dan menurunkan jumlah muatan negatif gugus fungsional asam humat sehingga akan menurunkan gaya tolak-menolak antar gugus dalam molekul asam humat. Dalam larutan pH 3-9 asam humat membentuk sistem koloid polielektrolit linear yang bersifat fleksibel.

Karakteristik fisik dari asam humat diketahui berdasarkan analisis dengan spektrofotometer UV-vis. Nilai absorbansi pada panjang gelombang maksimum, terjadi pada $200 \mathrm{~nm}$ menunjukkan adanya konjugasi $\mathrm{C}=\mathrm{C}$ dari struktur aromatik dimana asam humat sebagian besar strukturnya aromatik. Pada Gambar 1, asam humat hasil isolasi maupun standar memiliki serapan maksimum pada panjang gelombang $200 \mathrm{~nm}$.




Gambar 2. Kurva Absorbansi Asam Humat

Nilai rasio A254/A436sekitar 4-6 (Shirshova, 2006) dan didukung nilai standar adalah 4. Rasio E4/E6 digunakan untuk mengetahui tingkat aromatisasi suatu senyawa humat. Menurut Kononova (1966), rasio E4/E6 dari asam humat berkisar pada $< \pm 5$, sedangkan asam fulvat yaitu $>6$.

\section{Rendemen, Kadar Air dan Kadar Abu}

Kadar abu asam humat hasil isolasi adalah menunjukkan banyak mengandung mineral baik garam anorganik maupun organik. Nilai kadar air asam humat yang terbentuk pada $\mathrm{pH} 1,13$ (rendemen 3,75\%) kadar air 21,87\% dan kadar abu 17,21\%. Asam humat hasil isolasi yang mengendap pada $\mathrm{pH}$ 1,18 (rendemen 6,43\%), dengan kadar air 27,22\% dan kadar abu 17,39\% dan asam humat yang mengendap pada $\mathrm{pH} 2,24$ ( rendemen 12,35\%), kadar air 26,28\% dan kadar abu 17,50\%.

\section{Kadar C dan $N$}

Nilai rasio $\mathrm{C} / \mathrm{N}$ yang rendah menunjukkan bahan organik sudah terdekomposisi dengan sempurna dan hampir menjadi humus. Asam humat batubara.

Unsur terbanyak yang terkandung dalam asam humat yaitu karbon. Menurut Stevenson (1982) kandungan $\mathrm{C}$ pada asam humat yaitu 50-60\%, sedangkan kandungan $\mathrm{N}$ yaitu 0-2\%. Kadar $\mathrm{N}$ yang rendah menyebabkan mikroba sedikit sehingga proses dekomposisi dari bahan organik relatif lama. Nilai rasio $\mathrm{C} / \mathrm{N}$ yang semakin tinggi menunjukkan bahwa bahan organik belum terdekomposisi dengan baik/sempurna. Sedangkan rasio $\mathrm{C} / \mathrm{N}$ yang semakin kecil menunjukkan bahwa bahan organik sudah terdekomposisi dan hampir menjadi humus. Rasio $\mathrm{C} / \mathrm{N}$ asam humat hasil isolasi ditunjukkan pada Tabel 1.

Tabel 1. Nilai C/N Asam Humat Hasil Isolasi

\begin{tabular}{ccc}
\hline No. & Asam Humat & C/N \\
\hline 1 & AH pH 1,13 & 35,42 \\
2 & AH pH 1,18 & 20,44 \\
3 & AH pH 2,24 & 20,72 \\
\hline
\end{tabular}

\section{Kapasitas Tukar Kation}

Nilai kapasitas tukar kation (KTK) asam humat hasil isolasi yaitu 640,59 mek/100g. KTK mengindikasikan kapasitas kelat dari asam humat. Nilai KTK asam humat umumnya lebih besar 400 mek/100g (Tan, 1992) Salah satu faktor yang mempengaruhi pembentukan kelat yaitu $\mathrm{pH}$ larutan. Hasil pengamatan interaksi dengan larutan ion $\mathrm{Cu}^{2+}$ dengan asam humat hasil isolasi 
pada variasi $\mathrm{pH}$ 2-13 menunjukkan bahwa pada $\mathrm{pH} 5$ merupakan kondisi optimum dengan terbentuknya endapan dengan filtrat yang lebih bening dibandingkan $\mathrm{pH}$ lainnya. Pembentukan kelat ion $\mathrm{Cu}^{2+}$ karena adanya atom oksigen pada gugus karboksilat dan fenolat dari asam humat.

Spektrum IR asam humat hasil isolasi dan standar (Fluka, Switzerland) menunjukkan spektrum yang hampir sama yaitu pita-pita serapan utama pada $3400 \mathrm{~cm}-1,2900 \mathrm{~cm}-1,1700 \mathrm{~cm}-$ $11620 \mathrm{~cm}-1,1400-1300 \mathrm{~cm}-1$, dan $1050 \mathrm{~cm}-1$. Intensitas pita yang kuat terjadi pada $3434,28 \mathrm{~cm}-$ 1 yang mengindikasikan bahwa asam humat batubara mengandung $\mathrm{OH}$ atau $\mathrm{NH}$ yang banyak .



Gambar 3. Spektrum IR asam humat hasil isolasi pH 2,24; $\mathrm{pH}$ 1,13; pH 1,18; asam humat standar, asam humat t $\mathrm{pH} 1$

Pita 2918-2852 cm-1 menunjukkan regangan C-H alifatik dimana asam humat dari tanah gambut dan standar menunjukkan pita lebih kuat dibandingkan asam humat dari batubara. Pada pita 1742,70-1701,23 cm-1 asam humat dari tanah gambutdan standar menunjukkan intensitas lebih kuat mengindikasikan pada asam humat tanah gambut lebih banyak mengandung gugus karboksilat. Dari spektrofotometri UV-vis asam humat batubara lebih melimpah struktur aromatik yang ditunjukkan adanya pita kuat pada 1614-1602 cm-1. Berdasarkan hal tersebut dapat diduga bahwa asam humat dari batubara lebih banyak mengandung aromatik dan gugus $\mathrm{OH}$ sedangkan asam humat tanah gambut lebih banyak mengandung alifatik dan gugus karboksilat.

\section{Daya Serap Asam Humat Terhadap Ion Logam Pb(II), Cu(II) dan Fe(II)}

Waktu kontak optimum merupakan waktu yang dibutuhkan asam humat untuk menyerap ion-ion logam paling banyak. Optimasi waktu kontak dilakukan pada variasi 30, 60, 90, 120, 
150, dan 180 menit. Hasil penentuan waktu optimum asam humat dengan ion-ion logam ditunjukkan dalam Gambar 3.

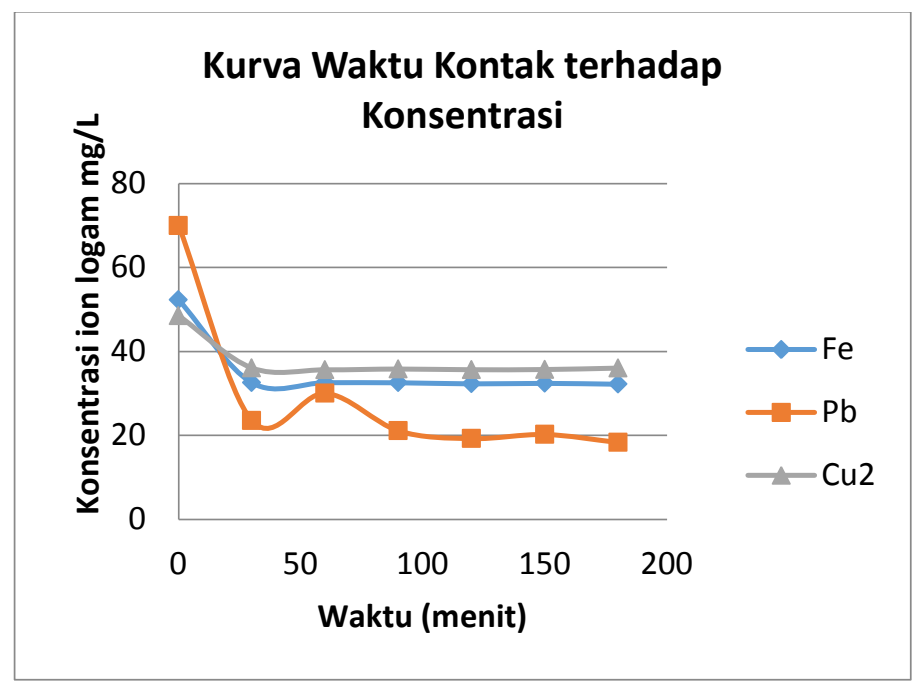

Gambar 4. Kurva Waktu Kontak (menit) Terhadap Konsentrasi Ion Logam.

Semakin lama waktu kontak, penyerapan ion logam oleh asam humat semakin besar ion logam yang terserap, tetapi sampai waktu kontak tertentu ion logam yang terserap akan stabil dan selanjutnya kemungkinan akan menurun. Hal ini terjadi karena adanya desorpsi dari ion logam tersebut. Waktu kontak optimum untuk logam $\mathrm{Pb}(\mathrm{II})$ adalah 100 menit, sedangkan untuk ion logam $\mathrm{Cu}(\mathrm{II})$ dan $\mathrm{Fe}(\mathrm{II})$ sama yaitu 60 menit.

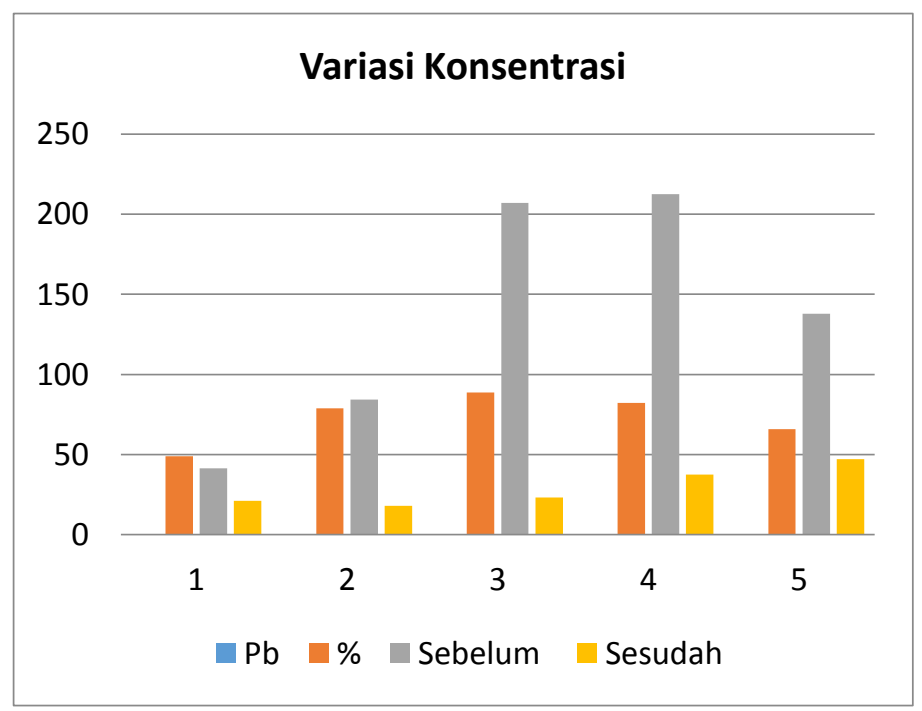

Gambar 5. Kurva adsorpsi $\mathrm{Pb}$ oleh asam humat dengan variasi konsentrasi $\mathrm{Pb}$ 
Penyerapan logam $\mathrm{Pb}$ (II) menunjukkan prosentase 48,9\% sampai dengan 88,73\%. Penyerapan logam $\mathrm{Cu}$ (II) menunjukkan prosentase $4,15 \%$ sampai dengan $13,29 \%$. Penyerapan logam $\mathrm{Fe}(\mathrm{II})$ menunjukkan prosentase $3,77 \%$ sampai dengan $34,78 \%$.

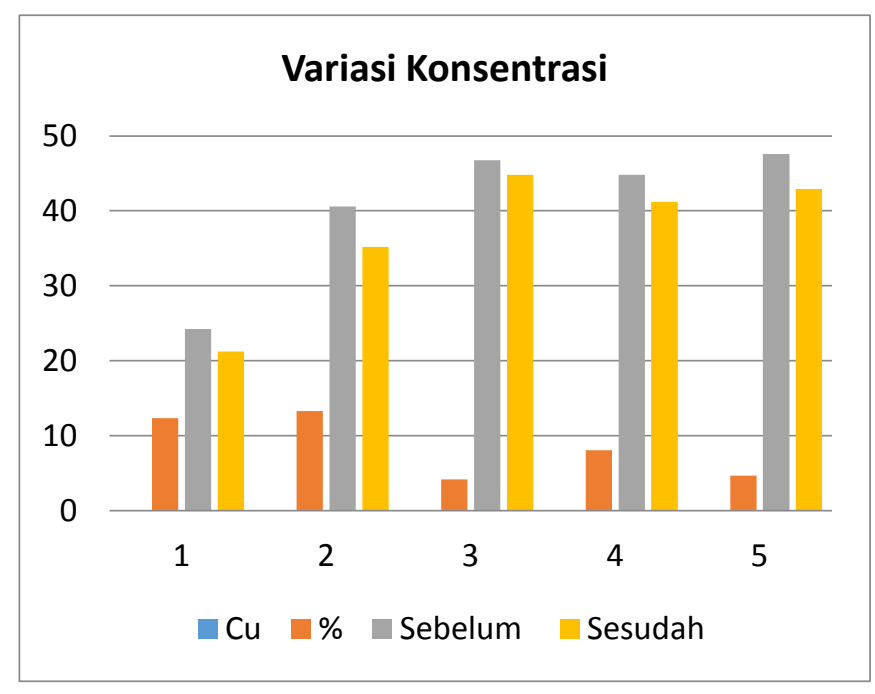

Gambar 6. Kurva Adsorpsi Cu oleh Asam Humat dengan Variasi Konsentrasi $\mathrm{Cu}$

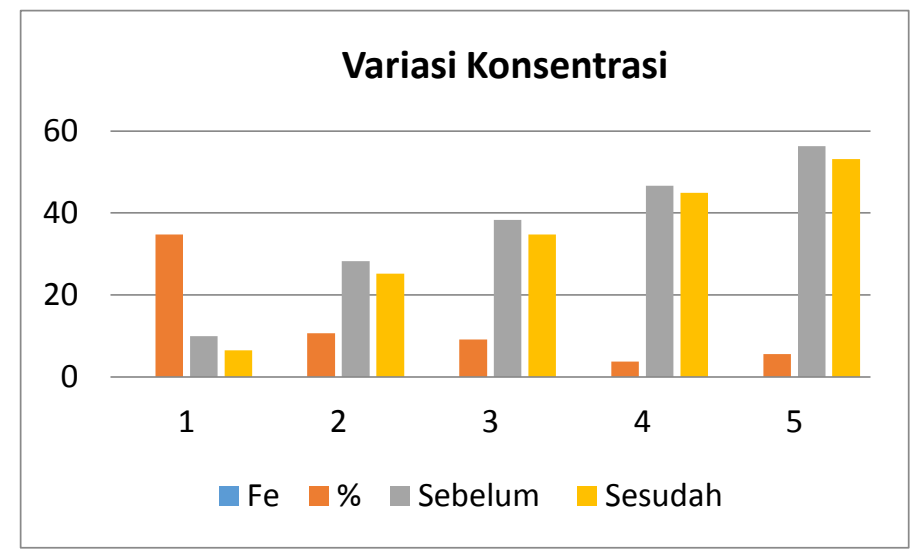

Gambar 7. Kurva Adsorpsi Fe oleh Asam Humat dengan Variasi Konsentrasi Fe

\section{PENUTUP}

Kesimpulan

Kesimpulan dalam penelitian ini adalah sebagai berikut: 
1. Asam humat dapat diisolasi dari batubara menggunakan natrium karbonat dengan rendemen yang cukup banyak dan sifat asam humat hasil isolasi secara umum telah sesuai dengan ciriciri asam humat standar, natrium karbonat merupakan zat pengekstrak yang baik (efektif) untuk isolasi asam humat.

2. Asam humat dapat mengadsorpsi ion logam $\mathrm{Pb}(\mathrm{II}), \mathrm{Cu}(\mathrm{II})$ dan $\mathrm{Fe}(\mathrm{II})$; Daya serap asam humat terhadap ion logam bervariasi tergantung dari sifat ion logamnya.

\section{Ucapan Terima Kasih}

Penulis menyampaikan rasa terima kasih kepada Putri Damayanti dan Ade Ikhsaniah yang banyak membantu dalam penelitian ini.

\section{DAFTAR PUSTAKA}

Aiken, G.R., McKnight, D.M., Wershaw, R.I., and MacCarthy, P., 1985, Humic Substances in Soil, Sediment and Water : Geochemistry, Isolation, and Characterization, John Wiley \& Sons, New York

Alimin, Narsito, Sri Juari S, dan Sri Noegrohati. 2005. Fraksinasi Asam Humat dan Pengaruhya pada Kelarutan Ion Logam Seng (II) dan Kadmium (II) : Jurnal Ilmu dasar. 6/1 :1-9.

Chen,Y., Senesi,N., \& Schnitzer, M. (1997). Information Provided on Humic Substances by E4/E6 Rations. Soil Sci.Am.J.,41(41), 352-358.

Korodi Gyula. 2011. Application of humic acids and their derivatives in environmental pollution control. Hungary; Journal of AARMS. 11, No. 1 (2012), 61-65.

Prasasti, D. Juari, S. Sudiono, S. 2012, Studi Kapasitas Adsorpsi-Reduksi ion Au(III) Pada Asam Humat Hasil Isolasi Dari Tanah Gambut Rawa Pening : Jurnal Ilmiah Kefarmasian. 2/2 : 141-151.

Shirshova, L.T., Ghabbour, E.A., \& Davies, G.(2006). Spectroscopic Characterization of Humic Acid Fractions Isolated From Soil Using Different Extraction Procedure.Geoderma, 133(34), 204-217.

Tatzber, M., Stemmer, M.,Spiegel, H.,Katzlberger, C., Haberhauer, G., Mentler, A., \& Gerzabek, M.H. (2007).FTIR-spectroscopic characterization of humic acids and humin fractions obtained by advanced $\mathrm{NaOH}, \mathrm{Na} 4 \mathrm{P} 2 \mathrm{O} 7$, and $\mathrm{Na} 2 \mathrm{CO} 3$ extraction procedures.Journal of Plant Nutrition and Soil Science, Volume 170, Issue 4, pages 522-529.

Stevenson, F.S. (1994). Humus Chemistry; Genesis, Composition, Reactions. Interscience Publication. John Willey \& Sons, Inc New York.

Sudarmadji, S. Bambang H, Suhardi. 2007. Analisis Bahan Makanan dan Pertanian. Libberly. Yogyakarta.

Tan, K.H. (1992). Prinsiple of Soil Chemistry. Marcel Decker, Inc. Newyork.

Yong R and Cynthia A. 2006. Humic acid preparation, properties and interactions with metals lead and cadmium. Canada; Journal of Engineering Geology, 85, 26-32. 
